\title{
Heavy Metal Distribution in Street Dust of Urban and Industrial Areas in Jeddah, Saudi Arabia
}

\author{
Mamdouh I. Khoder, Mansour A. Al Ghamdi, \\ and Mohamed H. Shiboob \\ Environmental Science Department, Faculty of Meteorology, \\ Environment and Arid Land Agriculture, King Abdulaziz University, \\ Jeddah, Saudi Arabia.
}

\begin{abstract}
The concentrations of heavy metals namely: $\mathrm{Pb}, \mathrm{Ni}, \mathrm{Cd}, \mathrm{Cr}$, $\mathrm{Cu}, \mathrm{Zn}, \mathrm{Fe}$ and $\mathrm{Mn}$ were measured in street dust samples. The samples were collected from the urban (Aljamaa district, main streets and substreets) and industrial areas of Jeddah city, Saudi Arabia. The concentrations of the measured metals were significantly higher in the main streets of the urban area than those found in the industrial area and substrates of the urban area. However, $\mathrm{Pb}$ was found in the highest levels in industrial area. The concentrations of the individual metals in street dust collected from the main streets and substreets of the urban area and industrial area averaged 70.36, 53.51 and 105.76 $\mu \mathrm{g} / \mathrm{g}$ for $\mathrm{Pb} ; 39.71,24.00$ and $27.28 \mu \mathrm{g} / \mathrm{g}$ for $\mathrm{Ni} ; 2.24,1.32$ and 1.57 $\mu \mathrm{g} / \mathrm{g}$ for $\mathrm{Cd} ; 72.93,40.10$ and $47.67 \mu \mathrm{g} / \mathrm{g}$ for $\mathrm{Cr} ; 125.52,83.32$ and $93.66 \mu \mathrm{g} / \mathrm{g}$ for $\mathrm{Cu} ; 340.85,214.10$ and $240.50 \mu \mathrm{g} / \mathrm{g}$ for $\mathrm{Zn} ; 10199.42$, 7678.84 and $7918.42 \mu \mathrm{g} / \mathrm{g}$ for Fe and 514.15, 389.69 and $400.64 \mu \mathrm{g} / \mathrm{g}$ for $\mathrm{Mn}$, respectively. The ratios of main streets/substreets metal concentration in the urban area were 1.31, 1.65, 1.70, 1.82, 1.51, 1.59, 1.33 and 1.32 for $\mathrm{Pb}, \mathrm{Ni}, \mathrm{Cd}, \mathrm{Cr}, \mathrm{Cu}, \mathrm{Zn}, \mathrm{Fe}$ and $\mathrm{Mn}$, respectively. The mean concentrations of measured heavy metals in street dust from both study areas were lower / higher or similar to those detected in other cities of the world. The average concentrations of $\mathrm{Cu}$ and $\mathrm{Zn}$ in street dust of the main street dusts of the urban area exceeded the permissible limit value of soil. Significant positive correlation coefficients were found between the concentrations of $\mathrm{Cr}, \mathrm{Cd}, \mathrm{Cu}$ and $\mathrm{Zn}$ and also between the concentrations of $\mathrm{Fe}, \mathrm{Mn}$ and $\mathrm{Ni}, \mathrm{Cr}, \mathrm{Cu}$ and $\mathrm{Zn}$ in the street dust of the urban area. On the other hand, insignificant positive correlation coefficients were found between the concentrations of $\mathrm{Pb}$ and other metals in street dust of the urban area. In the industrial area, significant positive correlation coefficients were found between the concentrations of heavy metals in the street dust.
\end{abstract}


Keywords: Heavy metals, street dust, urban, industrial, main streets, substreets, Jeddah.

\section{Introduction}

Street dust makes a significant contribution to the pollution in the urban environment (Al-Khashman, 2004). Heavy metals may come from many different sources in urban areas, including vehicle emission, industrial discharges, domestic heating, long-range transport and weathered materials (Li et al., 2001; Al-Khashman, 2004; Viard et al., 2004; Grigalaviciene et al., 2005 and Al-Khashman and Shawabakh, 2006). Street dust metal pollution in urban areas arises from a variety of sources via water transported material from surrounding soils and slopes, dry and wet atmospheric deposition, biological inputs, road surface wear, road paint degradation, vehicular emissions, vehicle wear and lubricating oil, industrial emissions, fuels combustion and particulate emissions (Sutherland and Tolosa, 2000; Banerjee, 2003 and López et al., 2005). The key heavy metals are $\mathrm{Pb}$ from leaded gasoline, $\mathrm{Cu}, \mathrm{Zn}$ and $\mathrm{Cd}$ from car components, tire wear abrasion, lubricants, industrial and incinerator emissions (Markus and McBratney, 1996; Wilcke et al., 1998 and Ozkan et al., 2005). Cd is used in accumulators of motor vehicles or in carburetors as alloys and it is released after combustion (Olajire and Ayodele, 1997 and Arslan, 2001). The $\mathrm{Ni}$ and $\mathrm{Cr}$ sources in street dust are believed to be corrosion of cars and chrome plating of some motor vehicle parts (Akhter and Madany, 1993 and Al-Shayep and Seaward, 2001). $\mathrm{Zn}$ is a component of tires, which is released as they wear (Doss et al., 1995).

Street dust has a particular concern due to its potential health risk to children through hand-to mouth activities, important source of house dust and urban atmospheric particulate matter and being inhaled by those traversing the streets and those residing in the vicinity of the streets (Ljung et al., 2005 and Acosta et al., 2009). It carries a high loading of contaminants such as metals and organic pollutants (Kim et al., 1998; Li et al., 2001 and Yunker et al., 2002). Due to the non-biodegradability of heavy metals and their long biological half-lives, their accumulations in the food chain have a significant effect on human health in the long term (Alloway, 1990 and Kabata-Pendias and Pendias, 1992). Metals pollution accumulates in the street dust, soil, and surface and influences both the population health and ecosystem (Tüzen, 2003 and Ferreira-Baptista and 
De Miguel, 2005). During rain periods, the dust usually gets discharged in the adjoining marine environment that could seriously pollute the water and concentrate in the sediments of the coastal area. This may prove toxic to marine life and contaminate fish or shellfish (Chirenje et al., 2006).

Heavy metals cause toxic effects (Massadeh et al., 2006). Human exposure to high concentrations of heavy metals leads to their accumulation in the fatty tissues of the human body and affects the central nervous system, or may be deposited in the circulatory system and disrupt the normal functioning of the internal organs (Waisberg et al., 2003 and Bocca et al., 2004). Lead poisoning causes permanent neurological, developmental, and behavioral disorders, particularly in children (Laidlaw et al., 2005). Some trace metals (e.g. $\mathrm{Cu}$ and $\mathrm{Zn}$ ) at low concentrations are harmless, but other (e.g. Pb and $\mathrm{Cd})$ at extremely low concentrations are toxic and initiators or promoters in many diseases and cancer (Willers et al., 2005).

The monitoring of the metal contents of dust samples is an efficient way of obtaining information on the current environmental state of large areas. There is a lack of information on the concentrations of heavy metals in street dust of Jeddah, Saudi Arabia, which may provide important information on the state of the environmental pollution of urban and industrial areas, and to be used as a useful indicator of the heavy metal pollution sources. Therefore, the present study aims to (1) reduce that lack by evaluating the distribution of some heavy metals $(\mathrm{Pb}$, $\mathrm{Ni}, \mathrm{Cd}, \mathrm{Cr}, \mathrm{Cu}, \mathrm{Zn}, \mathrm{Fe}$ and $\mathrm{Mn}$ ) in street dust samples collected from the urban and industrial areas in Jeddah, (2) compare the concentrations of heavy metals between the main streets and substreets in the urban area, (3) compare the heavy metal results from both study areas with those available in various areas throughout the world, and (4) investigate the factors effecting on the metal concentrations in the street dust.

\section{Materials and Methods}

\section{Study Area}

Jeddah is the second largest city of Saudi Arabia and is located on the Red Sea coast in the western part of Saudi Arabia. It is surrounded by mountains from north-east, east and south-east. Jeddah is a large 
commercial and industrial center as well as the crossroads between East and West to Asia, Africa and Europe. The general climate of Jeddah is warm and humid but moderate in winter, however in summer; it is characterized by high temperature, humidity, and solar radiation. Rainfall is generally sparse. Two sampling areas in Jeddah were selected according to traffic density and industrial activities. The first area was in Aljamaa district, which represented the urban area, located south of Jeddah city and characterized by relatively high traffic density. The second one was in industrial area, located south of Jeddah city, south of Aljamaa district.

\section{Sample Collection}

Street dusts were sampled during October - November 2010, to avoid rain washing out the heavy metals. A sampling point within each area was randomly selected. The sampling was carried out by sweeping an area of about $1 \mathrm{~m}^{2}$ from pavement edges using a plastic dustpan and brushes (Christoforidis and Stamatis, 2009). The samples were collected from both sides of the road. Street dusts were not collected from sites adjacent to specific pollution sources (e.g. industries or gasoline sites). The samples were transferred to air-tight polyethylene bags until transport to the laboratory. Dust samples were stored in small self-sealing plastic bags after air-drying at room temperature, and then sieved through a $1.0 \mathrm{~mm}$ mesh nylon sieve to remove extraneous material. Samples were homogenized and sieved through $63 \mu \mathrm{m}$ sieve size. This size is chosen because dust may contain higher metal concentrations (Whicker et al., 1997), and particles below this size are considered hazardous (Duggan and Inskip, 1985). Dust samples were moisture equilibrated for at least $12 \mathrm{~h}$ in desiccators and weighted. After weighting, the street dust samples were digested for the metal analysis.

\section{Heavy Metal Analysis}

Known weight $(0.5 \mathrm{~g})$ of dust fractions $(<63 \mu \mathrm{m})$ were subjected to chemical extraction using a 1:3 mixture of concentrated hydrochloric and nitric acid (Harrison and Perry, 1986). The clear digested solutions were made to $50 \mathrm{ml}$ with double-distilled water, and stored in plastic bottles. $\mathrm{Pb}$, $\mathrm{Ni}, \mathrm{Cd}, \mathrm{Cr}, \mathrm{Cu}, \mathrm{Zn}, \mathrm{Fe}$ and $\mathrm{Mn}$ concentrations in the final solutions were determined using a Varian Atomic Absorption Spectrometer (AAS) Spectra AA-220-FS. All solvents and chemicals used were analytical reagent grade. All the glassware and plastic vessels were treated by dilute (1:1) nitric acid 
and then rinsed with double distilled water before use. Double-distilled water was used for preparing the stock solutions of target metals and all dilutions. Calibration curves for each target metals were obtained by using suitable standard solutions prepared from the stock solutions. For all measured metals, good correlation was found with $\mathrm{R}^{2}>0.995$. The reproducibility expressed as relative standard deviation (RSD) for replicate analyses of the calibration standard for all measured metals varied from $1.99 \%$ to $3.89 \%$. The detection limit of each metal was calculated from the data of replicate measurements of low concentration samples and observed from their standard deviation. The instrument was calibrated using metal standards for each element being analyzed. In order to determine the precision of the analytical process, sample from one site was analyzed four times. The RSD for this sample was calculated to $2.5 \%$. Laboratory blanks were prepared by adding same volume of a 1:3 mixture of concentrated hydrochloric and nitric acid that was added to the samples to a conical flask containing none of the samples being investigated. This consisted of all components added to the matrix during digestion. Blank samples were analyzed for total trace metal levels. The relative concentration in percentage of an element in the sum of elements was calculated and the formula is: Percentage of $X=X /$ (sum of all elements) * 100\%.

\section{Statistical Analysis}

The correlation coefficient (r) and the correlation significant t-test were determined using the alternative method of calculation (Gregory, 1963). Student's t-test was used to estimate the significant difference between the mean concentrations of heavy metals (Gregory, 1963).

\section{Results and Discussion}

\section{Heavy Metals in Street Dust}

The minimum, maximum, median and arithmetic mean concentrations of the individual measured heavy metals in the street dust collected from the main streets of the urban and industrial areas are summarized in Table 1. Fe, Mn and $\mathrm{Zn}$ were the abundant metals, however $\mathrm{Cd}$ was found in the lowest concentrations. The distribution of the individual measured metals were found to follow the pattern of $\mathrm{Fe}>$ $\mathrm{Mn}>\mathrm{Zn}>\mathrm{Cu}>\mathrm{Cr}>\mathrm{Pb}>\mathrm{Ni}>\mathrm{Cd}$ in the main street of the urban area and $\mathrm{Fe}>\mathrm{Mn}>\mathrm{Zn}>\mathrm{Pb}>\mathrm{Cu}>\mathrm{Cr}>\mathrm{Ni}>\mathrm{Cd}$ in the industrial area 
(Fig. 1). The mean relative concentrations of the individual metals in the street dust of both urban and industrial areas were, respectively, $0.62 \%$ and $1.20 \%$ for $\mathrm{Pb}, 0.35 \%$ and $0.31 \%$ for $\mathrm{Ni}, 0.02 \%$ and $0.018 \%$ for $\mathrm{Cd}$, $0.64 \%$ and $0.54 \%$ for $\mathrm{Cr}, 1.10 \%$ and $1.06 \%$ for $\mathrm{Cu}, 3.00 \%$ and $2.72 \%$ for Zn, $89.74 \%$ and $89.62 \%$ for Fe and $4.52 \%$ and $4.53 \%$ for Mn (Fig. 1).

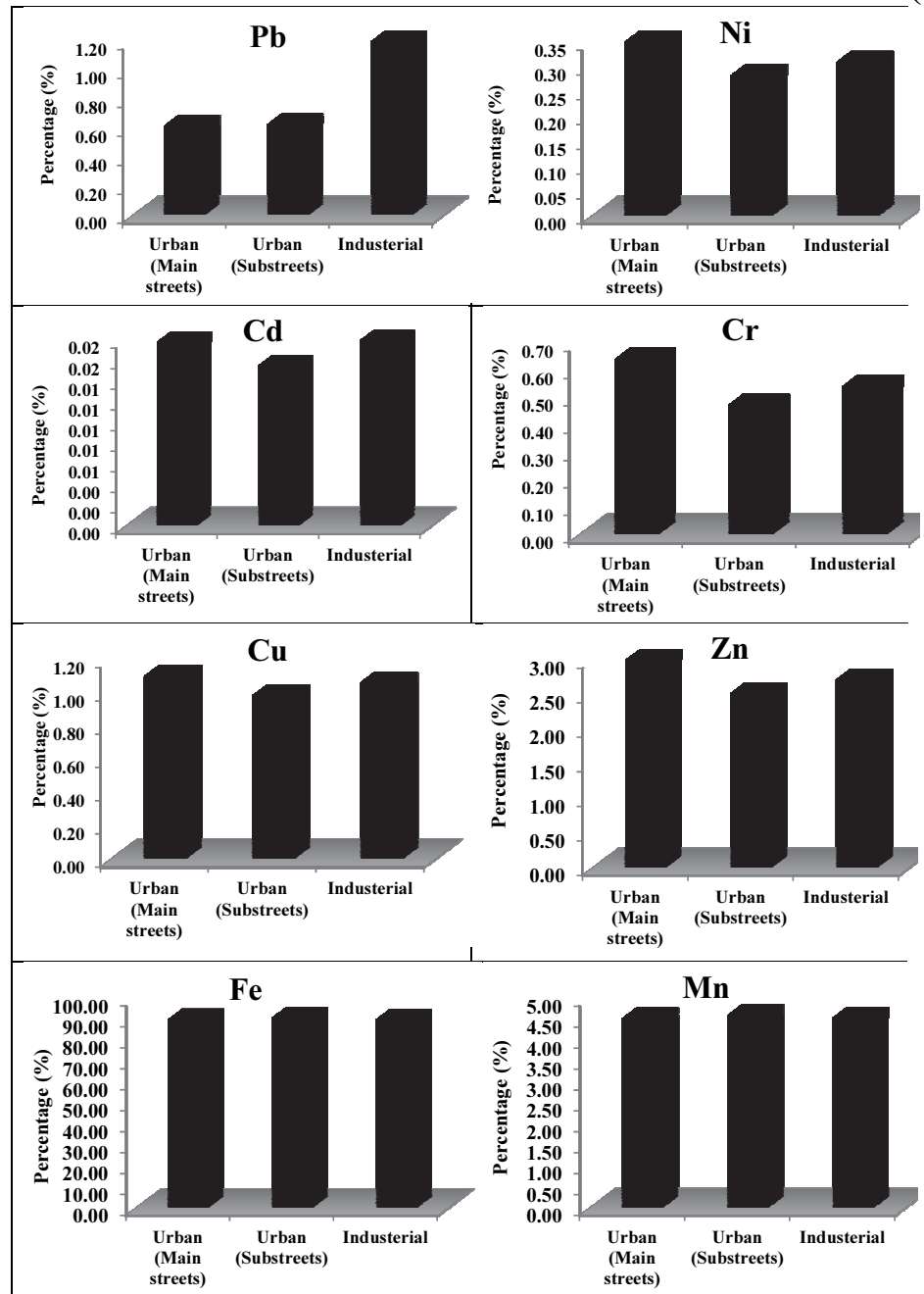

Fig. 1. The relative concentrations in percentage of the individual metals to the total concentrations of metals in street dusts collected from the urban (main streets and substreets) and industrial areas.

$\mathrm{Pb}$ pollution comes from combustion of gasoline that contains tetraethyl lead as an anti-knock agent (Tüzen, 2003). The highest lead concentrations have been detected in dust collected from streets carrying 
heavy traffic (Fergusson and Kim, 1991 and Divrikli et al., 2005). Although $\mathrm{Pb}$ has been banned in petrol for several years in Saudi Arabia, the concentration of $\mathrm{Pb}$ in street dust of urban area reflects the significant degree of historical $\mathrm{Pb}$ contamination and its long half-life, because $\mathrm{Pb}$ was used in fuel for decades. The average concentration of $\mathrm{Pb}$ in the street dust in the industrial area was significantly $(\mathrm{p}<0.001)$ higher $(1.5$ times) than that found in the main streets of the urban area (Table 1). The relatively high concentration of $\mathrm{Pb}$ in the industrial area is mainly attributed to accumulation of $\mathrm{Pb}$ emitted from industrial activities and traditional use of leaded gasoline for long time. $\mathrm{Pb}$ pollution occurs on a local scale by industrial emissions and on a larger scale by emissions from vehicles that use leaded gasoline (Koeppe, 1981; Celik et al., 2005 and Tume et al., 2008).

Although $\mathrm{Pb}$ has been completely removed from fuel in Saudi Arabia, $\mathrm{Pb}$ in the street dust of the main streets of the urban area could be considered as an indirect $\mathrm{Pb}$ source particularly at the highest congestion of traffic density. Li et al. (2004) reported that although the leaded petrol was banned in Hong Kong in 1999, the Pb contamination due to the historical use of $\mathrm{Pb}$ in petrol was still significant in the urban soils. High concentrations of $\mathrm{Pb}$ were found in settled dust in an urban area of Giza, Egypt despite decades of using unleaded gasoline (khoder et al., 2010).

The average concentration of $\mathrm{Ni}$ in the main street dusts of the urban area was significantly $(\mathrm{p}<0.001)$ higher $(1.46$ time $)$ than that found in the industrial area (Table 1). The relatively high concentrations of $\mathrm{Ni}$ in the main street dusts of the urban area may be attributed to high traffic density which increases the emissions. The highest concentration of $\mathrm{Ni}$ content in street dust was found in the streets with heavy traffic density (Al-Khashman, 2007). Ni pollution on a local scale is caused by emissions from vehicle engines that use $\mathrm{Ni}$ gasoline and by the abrasion and corrosion of Ni from vehicle parts (Al-Shayeb and Seaward, 2001). In the present study, significant differences $(p<0.001)$ was found between $\mathrm{Cd}$ concentrations in street dust collected from the main streets of the urban area and those collected from the industrial area (Table 1). The average $\mathrm{Cd}$ concentration in street dust from the main streets of the urban area was found to be 1.43 times higher than that found in the industrial areas. This result is in agreement with Al-Khashman (2007) who found that the highest mean $\mathrm{Cd}$ content was found in the streets with heavy traffic. Higher concentrations of $\mathrm{Zn}$ and $\mathrm{Cd}$ in heavy traffic zones 
indicate that fragmentation of car tires is a likely source of these metals (Elik, 2003). Cd is released as a combustion product in the accumulators of motor vehicles or in carburetors (Charlesworth et al., 2003 and Divrikli et al., 2005).

The average concentration of $\mathrm{Cr}$ in the main street dust of the urban area was significantly $(\mathrm{p}<0.001)$ higher than that found in the industrial area (Table 1). The average $\mathrm{Cr}$ concentration in street dust was 1.53 times higher in the main streets of the urban area than in the industrial area. This result agrees with Al-Khashman (2007) and Christoforidis and Stamatis (2009) who found that the highest concentrations of $\mathrm{Cr}$ in the street dusts with heavy traffic density. In addition, $\mathrm{Cr}$ in dust is associated with the chrome plating of some motor vehicle parts (AlShayep and Seaward, 2001). In the present study, $\mathrm{Cu}$ concentrations in the street dust collected from the main streets of the urban area were significantly higher $(\mathrm{p}<0.01)$ than those found in the industrial area (Table 1).

Table 1. Summary statistics of the heavy metal concentrations in the street dust collected from the urban (main streets) and industrial areas.

\begin{tabular}{|c|c|c|c|c|c|c|c|c|c|c|}
\hline \multirow{2}{*}{ Metal } & \multicolumn{5}{|c|}{ Urban (Main streets) } & \multicolumn{5}{|l|}{ Industerial } \\
\hline & Minimum & Maximum & Median & Mean & S.D. ${ }^{\mathrm{a}}$ & Minimum & Maximum & Median & Mean & S.D. \\
\hline $\mathrm{Pb}$ & 40.45 & 115.10 & 58.64 & 70.36 & 24.94 & 66.94 & 179.00 & 97.36 & 105.76 & 28.49 \\
\hline $\mathrm{Ni}$ & 30.00 & 47.65 & 39.40 & 39.71 & 4.73 & 15.20 & 44.00 & 25.83 & 27.28 & 7.61 \\
\hline $\mathrm{Cd}$ & 1.61 & 3.17 & 2.06 & 2.24 & 0.45 & 0.69 & 3.06 & 1.55 & 1.57 & 0.50 \\
\hline $\mathrm{Cr}$ & 55.90 & 98.85 & 72.83 & 72.93 & 12.34 & 16.17 & 78.00 & 45.00 & 47.67 & 16.01 \\
\hline $\mathrm{Cu}$ & 71.15 & 157.95 & 131.03 & 125.52 & 22.42 & 60.64 & 175.46 & 80.90 & 93.66 & 36.64 \\
\hline $\mathrm{Zn}$ & 266.45 & 476.75 & 323.18 & 340.85 & 57.69 & 100.20 & 419.70 & 245.45 & 240.50 & 101.35 \\
\hline $\mathrm{Fe}$ & 7796.00 & 11802.00 & 10439.00 & 10199.42 & 1138.52 & 4941.92 & 14038.92 & 7074.10 & 7918.42 & 2633.00 \\
\hline $\mathrm{Mn}$ & 352.00 & 630.00 & 525.50 & 514.15 & 74.17 & 141.90 & 846.80 & 367.34 & 400.64 & 143.41 \\
\hline
\end{tabular}

${ }^{\text {aStandard deviation }}$

The average $\mathrm{Cu}$ concentration in street dust from the main streets of the urban area was found to be 1.34 times higher than that found in the industrial areas. $\mathrm{Cu}$ concentrations ranged from 71.15 to $157.95 \mu \mathrm{g} / \mathrm{g}$ (with a mean value of $125.52 \mu \mathrm{g} / \mathrm{g}$ ) in the main streets of the urban area and 60.64 to $175.46 \mu \mathrm{g} / \mathrm{g}$ (with a mean value of $93.66 \mu \mathrm{g} / \mathrm{g}$ ) in the industrial area. This may be attributed to the higher traffic density which leads to an increase in cu emission. The highest levels of $\mathrm{Cu}$ were observed in the street dust samples from heavy traffic areas (A1Khashman, 2007). Cu source in the street dust was ascribed to corrosion of the metallic parts of cars like engine wear, thrust bearing, and brush wear (Divrikli et al., 2005 and Al-Khashman and Shawabkeh, 2006). 
The average concentration of $\mathrm{Zn}$ in the main street dusts of the urban area was significantly $(\mathrm{p}<0.001)$ higher than that found in the industrial area (Table 1). The average $\mathrm{Zn}$ concentration in street dust from the main streets of the urban area was 1.42 times higher than that found in the industrial areas. The highest levels of $\mathrm{Zn}$ were found in the street dust samples from heavy traffic areas (Al-Khashman, 2007). The elevated concentrations of $\mathrm{Cu}, \mathrm{Zn}$ and $\mathrm{Ni}$ can be attributed to the heavy traffic near the sampling site (Sternbeck et al., 2002 and Harrison et al., 2003). $\mathrm{Zn}$ particles may be derived from industrial sources, with the abrasion of tires of motor vehicles a possible second source (Adriano, 2001 and Carreras and Pignata, 2002). In the present study, Fe was the most abundant metal content in the street dust. Fe concentrations in street dust collected from the main streets of the urban area were significantly higher $(\mathrm{p}<0.001)$ than those found in the industrial area (Table 1).

The concentrations of Fe ranged from 7796 to $11802 \mu \mathrm{g} / \mathrm{g}$ (with a mean value of $10199.42 \mu \mathrm{g} / \mathrm{g}$ ) in the main streets of the urban area and 4941.92 to $14038.92 \mu \mathrm{g} / \mathrm{g}$ (with a mean value of $7918.42 \mu \mathrm{g} / \mathrm{g}$ ) in the industrial area. The average Fe concentration in street dust from the main streets of the urban area was found to be 1.29 times higher than that found in the industrial areas. The highest levels of Fe in street dust collected from the main streets of the urban area may be attributed to the pollution originating from heavy traffic density and anthropogenic activities. This is in agreement with Al-Khashman (2007) who found the highest levels of Fe in the street dust samples from heavy traffic areas. The possible sources of Fe in street dust were believed to be wear of brake linings material, corrosion and wear of the vehicles (Hildemann et al., 1991 and Garg et al., 2000). In the present study, the average concentration of $\mathrm{Mn}$ in the main street dusts of the urban area was significantly $(\mathrm{p}<0.01)$ higher than that found in the industrial area (Table 1). The average Mn concentration in street dust from the main streets of the urban area was 1.28 times higher than that found in the industrial areas. The highest levels of $\mathrm{Mn}$ were found in the street dust samples from heavy traffic areas (Al-Khashman, 2007). The main source of $\mathrm{Mn}$ in dust samples was from the geological material, traffic, and tire wear (Divrikli et al., 2005).

$\mathrm{Fe}, \mathrm{Mn}$ and $\mathrm{Zn}$ were the abundant street dust metals collected from the substreets of the urban areas (Fig. 2). The distribution of the individual measured metals in substreet dust were found to follow the 
pattern $\mathrm{Fe}>\mathrm{Mn}>\mathrm{Zn}>\mathrm{Cu}>\mathrm{Pb}>\mathrm{Cr}>\mathrm{Ni}>\mathrm{Cd}$. The mean relative concentrations of the individual metals in substreets dust were $0.63 \%$ for $\mathrm{Pb}, 0.28 \%$ for $\mathrm{Ni}, 0.02 \%$ for $\mathrm{Cd}, 0.47 \%$ for $\mathrm{Cr}, 0.98 \%$ for $\mathrm{Cu}, 2.52 \%$ for $\mathrm{Zn}, 90.50 \%$ for $\mathrm{Fe}$ and 4.59 for $\mathrm{Mn}$ (Fig. 1). The highest metal concentrations were found in the main street dusts. Significant differences $(p<0.001)$ were found between the average concentrations of the individual metals in the main streets and substreets. The average concentrations of the individual metals in the dusts collected from the main and substreets were: 70.36 and $53.51 \mu \mathrm{g} / \mathrm{g}$ for $\mathrm{Pb}, 39.71$ and 24.00 $\mu \mathrm{g} / \mathrm{g}$ for $\mathrm{Ni}, 2.24$ and $1.32 \mu \mathrm{g} / \mathrm{g}$ for for $\mathrm{Cd}, 72.93$ and $40.1 \mu \mathrm{g} / \mathrm{g}$ for $\mathrm{Cr}$, 125.52 and $83.32 \mu \mathrm{g} / \mathrm{g}$ for $\mathrm{Cu}, 340.85$ and $214.10 \mu \mathrm{g} / \mathrm{g}$ for $\mathrm{Zn}, 10199.42$ and $7678.84 \mu \mathrm{g} / \mathrm{g}$ for $\mathrm{Fe}$ and 514.15 and $389.69 \mu \mathrm{g} / \mathrm{g}$ for $\mathrm{Mn}$, respectively (Fig. 2). In addition, the main street/substreets metal concentration ratios were $1.31,1.65,1.70,1.82,1.51,1.59,1.33$ and 1.32 for $\mathrm{Pb}, \mathrm{Ni}, \mathrm{Cd}, \mathrm{Cr}, \mathrm{Cu}, \mathrm{Zn}, \mathrm{Fe}$ and $\mathrm{Mn}$, respectively (Fig. 2). The highest concentrations of the measured heavy metals in the main street dusts are mainly attributed to the high emission of those metals from the heavy traffic density. Heavy metals such as $\mathrm{Cd}, \mathrm{Cu}, \mathrm{Pb}, \mathrm{Ni}, \mathrm{Fe}$ and $\mathrm{Zn}$ are often associated with traffic densities (Birmili et al., 2006 and Han et al., 2007). $\mathrm{Pb}$ and a variety of other metals concentrations of roadside and parking dust and vegetation are directly related to traffic density (Grigalaviciene et al., 2005; Hjortenkrans et al., 2006 and Tokalioglu and Kartal, 2006). $\mathrm{Pb}$ and $\mathrm{Cd}$ concentrations in roadside soils generally decreased with increasing distance from the main road (Bakirdere and Yaman, 2008). Soil pollution by heavy metals was generally concentrated in the first few meters to tens of meters on either side of the road pavement and then sharply decreased with distance far away from the road (Blok, 2005 and Nabulo et al., 2006). Piron-Frenet et al. (1994) found a correlation between traffic density and heavy metal deposited in the roadside soil. The exponential equation fits quite well for the variations of $\mathrm{Pb}, \mathrm{Cd}, \mathrm{Zn}$ and $\mathrm{Cu}$ contents with distance pollution sources (Zheng et al., 2010). In the present study, the higher concentrations of heavy metals in the main street dusts than those were found in the substreets indicated that, humans living along the main street with heavy traffic density may be exposed to higher concentrations of heavy metals.

Generally, the concentrations of all measured metals in street dust except $\mathrm{Pb}$ were significantly higher in the main streets of the urban area associated with high traffic density, followed by the industrial area and 
substreets of the urban area. This shows the extent to which automobiles and industries release these metals as pollutants into the environment. The results in the present study confirmed that the main reason of high concentrations of heavy metals localized in industrial and in urban roadsides are either related to industrial activity or the density of the traffic.

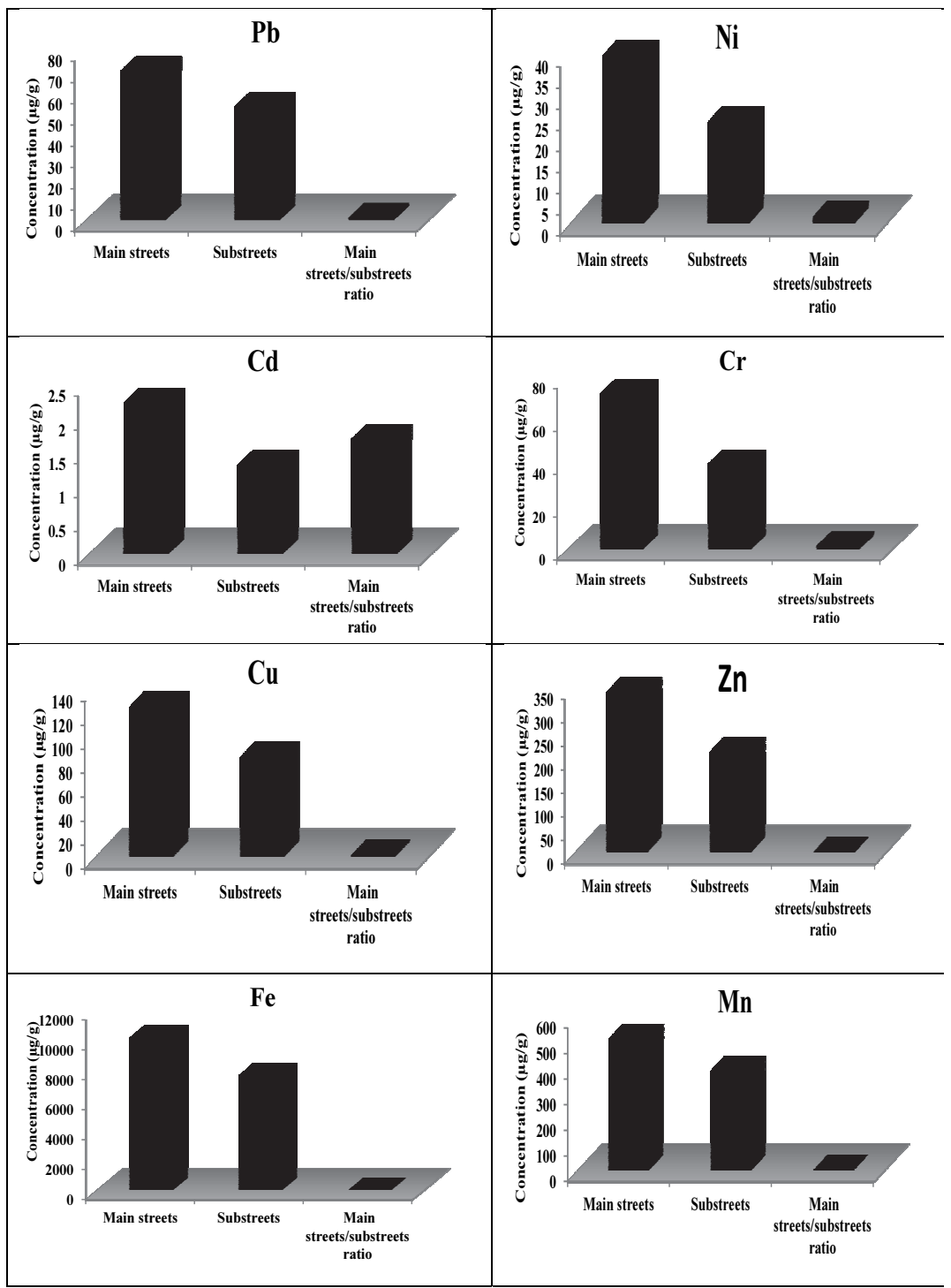

Fig. 2. Metal concentrations in street dust collected from the main streets and substreets of the urban area. 


\section{Comparison of Heavy Metals Levels in Street Dust of Jeddah with Other International Cities}

The heavy metal contents in street dust samples collected from the urban and industrial areas in Jeddah city were compared with those found in different locations of the world (Table 2). As shown in this Table, it could be seen clearly in general that, $\mathrm{Pb}, \mathrm{Cu}, \mathrm{Zn}, \mathrm{Ni}, \mathrm{Cr}, \mathrm{Cd}, \mathrm{Fe}$ and $\mathrm{Mn}$ mean values in street dust from both study areas were lower / higher or similar to those detected in other cities of the world. Generally, the variation in the levels of measured metals in street dusts among the different locations of the world was presumably due to the difference in the traffic density, industrial activities, and intensity of human activities, land use patterns and the frequency of rainfall prior to sample collection.

Until now, there are no guidelines for concentration of metals/metalloids in dusts (Leung et al., 2008). However, a substantial part of the street dust comes from soil re-mobilization/re-suspension while some of the street dusts are re-suspended and return to the soil surfaces (Charlesworth et al., 2003 and Ferreira-Baptista and De Miguel, 2005). Thus, it would be appropriate to compare the metal concentration in street dusts collected from different areas to the allowable limits in soil. The average concentrations of $\mathrm{Cu}$ and $\mathrm{Zn}$ found in the main streets only exceeded the maximum permissible limit $100 \mu \mathrm{g} / \mathrm{g}$ for $\mathrm{Cu}$ and 300 $\mu \mathrm{g} / \mathrm{g}$ for $\mathrm{Zn}$, respectively (Fabis, 1987 and Sezgin et al., 2003). The possible sources of $\mathrm{Cu}$ include wearing of machinery parts, and brake pads, however, Zn may have originated from wear and tear of vulcanized vehicle tires, and corrosion of galvanized automobile parts. Almost all the street dust samples collected from the main streets and substreets in the urban area as well as from industrial area were found to be very rich with crustal metals (Fe and $\mathrm{Mn}$ ). There is no limit on the concentration for these metals in the soil, but their extensive presence in all the sampling sites may be of concern due to their potential adverse health effects (Golub et al., 1992).

The average concentrations for $\mathrm{Pb}$ in street dust from the main streets $(70.36 \mu \mathrm{g} / \mathrm{g})$ and subtreets $(53.51 \mu \mathrm{g} / \mathrm{g})$ of the urban area were lower than the maximum permissible limit in the soil $(100 \mu \mathrm{g} / \mathrm{g}$, Fabis, 1987), whereas the average concentration for $\mathrm{Pb}$ in street dust from industrial area $(105.76 \mu \mathrm{g} / \mathrm{g})$ were nearly similar to this maximum permissible limit. 


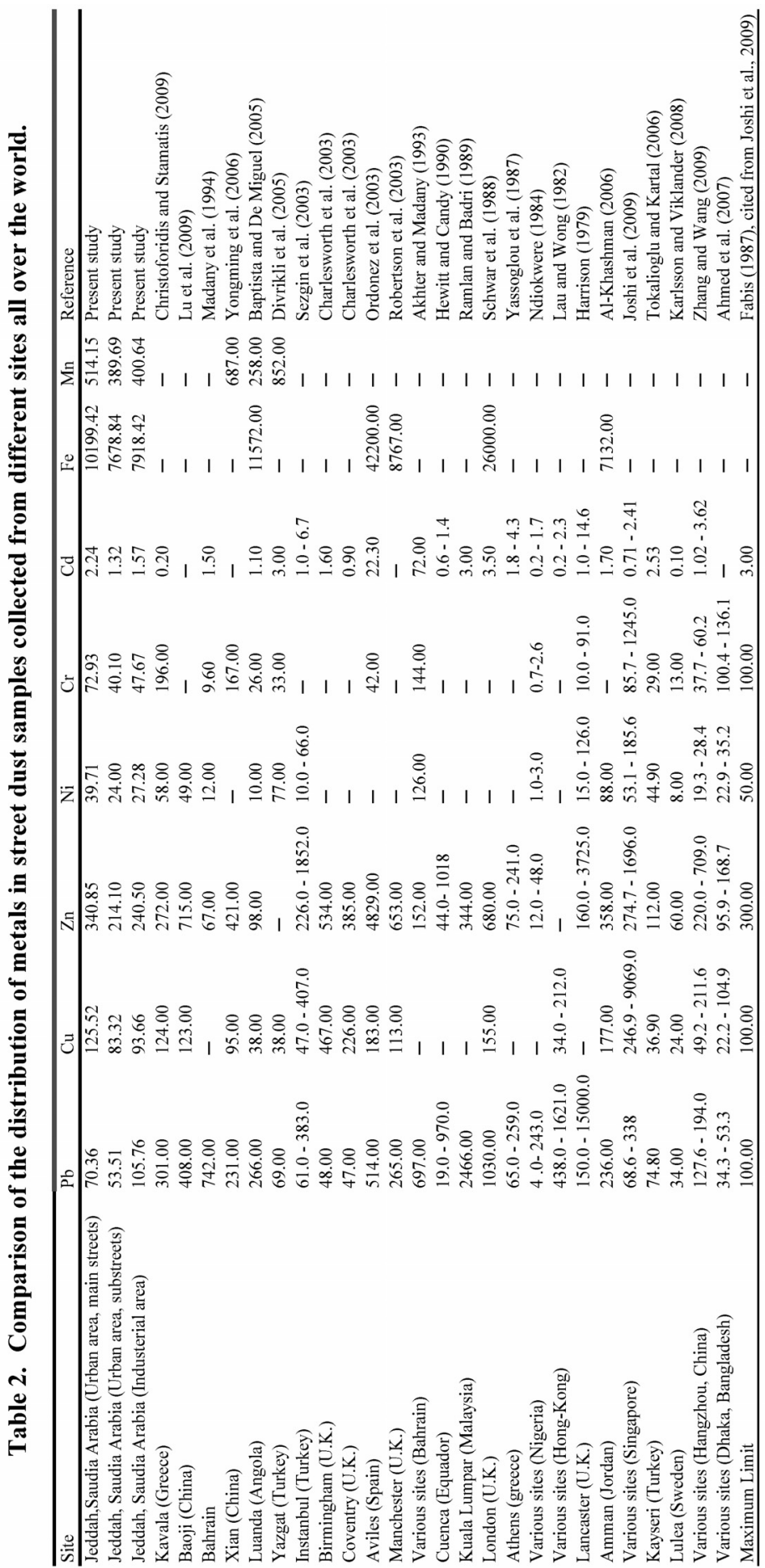




\section{Correlation Between the Street Dust Heavy Metal Concentrations}

Inter-element relationships can provide interesting information on the sources of heavy metal and their pathways (Manta et al., 2002). Correlation coefficients between the heavy metal concentrations in street dust collected from the urban and industrial areas are shown in Table 3. Significant positive correlation coefficients were found between the concentrations of $\mathrm{Cr}, \mathrm{Cd}, \mathrm{Cu}$ and $\mathrm{Zn}$ and between the concentrations of $\mathrm{Fe}, \mathrm{Mn}$ and $\mathrm{Ni}, \mathrm{Cr}, \mathrm{Cu}$ and $\mathrm{Zn}$ in the urban street dust. These relationships indicated that heavy traffic was the common contamination sources for heavy metals in the street dust of the urban area and the origin of the metals. Monaca et al. (2000) found positive relationships between $\mathrm{Cu}, \mathrm{Mn}, \mathrm{Pb}$, and $\mathrm{Zn}$ in urban environments in Florence, Italy. In the present study, insignificant positive correlation coefficients were found between the concentrations of $\mathrm{Pb}$ and other metals in street dust of the urban area (Table 3), due to the use of unleaded gasoline. Significant positive correlation coefficients were found between the concentrations of the measured metals in street dust collected from the industrial area. These correlations indicated that these metals originated from similar or co-located sources and the origin of the metals in the industrial area was highly related to the industrial activities and heavy traffic. The close relationships among $\mathrm{Cd}, \mathrm{Cu}, \mathrm{Pb}$ and $\mathrm{Zn}$ might indicate the combined soil pollution by multi-heavy metals as a result of long-term industrial and human activities (Lu and Bai, 2010).

Table 3. Correlation coefficients between the heavy metal concentrations in street dusts collected from the urban and industrial areas in Jeddah city.

\begin{tabular}{|c|c|c|c|c|c|c|c|c|}
\hline & $\mathrm{Pb}$ & $\mathrm{Ni}$ & $\mathrm{Cd}$ & $\mathrm{Cr}$ & $\mathrm{Cu}$ & $\mathrm{Zn}$ & $\mathrm{Fe}$ & Mn \\
\hline \multicolumn{9}{|c|}{ Urban area } \\
\hline $\mathrm{Pb}$ & 1 & 0.21 & 0.27 & 0.28 & 0.06 & 0.18 & 0.02 & 0.19 \\
\hline $\mathrm{Ni}$ & & 1 & $0.63^{c}$ & $0.80^{c}$ & $0.80^{c}$ & $0.57^{\mathrm{c}}$ & $0.46^{b}$ & $0.47^{\mathrm{b}}$ \\
\hline $\mathrm{Cd}$ & & & 1 & $0.69^{c}$ & $0.55^{\mathrm{c}}$ & $0.43^{b}$ & 0.13 & 0.18 \\
\hline $\mathrm{Cr}$ & & & & 1 & $0.68^{c}$ & $0.73^{c}$ & $0.45^{b}$ & $0.49^{\mathrm{b}}$ \\
\hline $\mathrm{Cu}$ & & & & & 1 & $0.53^{\mathrm{c}}$ & $0.46^{\mathrm{b}}$ & $0.42^{\mathrm{b}}$ \\
\hline $\mathrm{Zn}$ & & & & & & 1 & $0.40^{\mathrm{a}}$ & $0.42^{\mathrm{b}}$ \\
\hline $\mathrm{Fe}$ & & & & & & & 1 & $0.84^{\mathrm{c}}$ \\
\hline $\mathrm{Mn}$ & & & & & & & & 1 \\
\hline \multicolumn{9}{|c|}{ Industerial area } \\
\hline $\mathrm{Pb}$ & 1 & $0.66^{\mathrm{c}}$ & $0.48^{\mathrm{a}}$ & $0.72^{c}$ & $0.63^{c}$ & $0.60^{b}$ & $0.59^{b}$ & $0.43^{\mathrm{a}}$ \\
\hline $\mathrm{Ni}$ & & 1 & $0.75^{\mathrm{c}}$ & $0.75^{\mathrm{c}}$ & $0.73^{\mathrm{c}}$ & $0.78^{\mathrm{c}}$ & $0.69^{\mathrm{c}}$ & $0.59^{\mathrm{b}}$ \\
\hline $\mathrm{Cd}$ & & & 1 & $0.67^{\mathrm{c}}$ & $0.46^{\mathrm{a}}$ & $0.65^{c}$ & $0.63^{c}$ & $0.53^{\mathrm{b}}$ \\
\hline $\mathrm{Cr}$ & & & & 1 & $0.72^{c}$ & $0.67^{\mathrm{c}}$ & $0.56^{\mathrm{b}}$ & $0.51^{\mathrm{b}}$ \\
\hline $\mathrm{Cu}$ & & & & & 1 & $0.61^{\mathrm{c}}$ & $0.68^{\mathrm{c}}$ & $0.52^{\mathrm{b}}$ \\
\hline $\mathrm{Zn}$ & & & & & & 1 & $0.52^{b}$ & $0.60^{\mathrm{b}}$ \\
\hline $\mathrm{Fe}$ & & & & & & & 1 & $0.71^{\mathrm{c}}$ \\
\hline $\mathrm{Mn}$ & & & & & & & & 1 \\
\hline
\end{tabular}




\section{Conclusions}

The sources of the different metals in urban and industrial street dust were typically common to most urban and industrial environments, but their intensities and patterns of distribution varied according to the peculiarities of each city. The distribution of the individual measured metals in street dust was found to follow the pattern of $\mathrm{Fe}>\mathrm{Mn}>\mathrm{Zn}>$ $\mathrm{Cu}>\mathrm{Cr}>\mathrm{Pb}>\mathrm{Ni}>\mathrm{Cd}$ in the main street of the urban area, $\mathrm{Fe}>\mathrm{Mn}>$ $\mathrm{Zn}>\mathrm{Pb}>\mathrm{Cu}>\mathrm{Cr}>\mathrm{Ni}>\mathrm{Cd}$ in the industrial area and $\mathrm{Fe}>\mathrm{Mn}>\mathrm{Zn}>$ $\mathrm{Cu}>\mathrm{Pb}>\mathrm{Cr}>\mathrm{Ni}>\mathrm{Cd}$ in the substreet of the urban area. The highest metal concentrations were found in the main street dusts of the urban area, followed by the industrial area and substreets of the urban area. However, $\mathrm{Pb}$ was found in the highest concentrations in industrial area. The humans living along the main street with heavy traffic density may be exposed to higher concentration of metals. $\mathrm{Cu}$ and $\mathrm{Zn}$ in the main street dusts of the urban area exceeded the maximum permissible limit in soil. Correlation coefficients between the concentrations of measured metals in street dust indicated that heavy traffic density was the major source of the heavy metals in the urban street dust; however, industrial activities and emissions from vehicles were the major sources of these metals in the street dust of the industrial area. A regular monitoring program to assess the street dust quality is needed in order to implement suitable pollution control measures in the city environment.

\section{References}

Acosta J.A., Cano, A.F., Arocena, J.M., Debela, F. and Martínez- Martínez, S. (2009) Distribution of metals in soil particle size fractions and its implication to risk assessment of playground in Murcia City (Spain). Geoderma; 149: 101-9.

Adriano, D.C. (2001) Trace elements in terrestrial environments: Biogeochemistry, bioavailability, and risks of metals ( $2^{\text {nd }}$ edn., P. 867). New York: Springer.

Ahmed, F., Bibi, M.H. and Ishiga, H. (2007) Environmental assessment of Dhaka city (Bangladesh) based on trace metal contents in road dusts. Environ. Geol. 51: 975-985.

Akhter, M.S. and Madany, I.M. (1993) Heavy metal in street and house dust in Bahrain. Water, Air, and Soil Pollution, 66: 111-119.

Al-Khashman, O. (2006) Determination of metal accumulation in deposited street dusts in Amman, Jordan. Environmental Geochemistry and Health, 29(1): 1-10.

Al-Khashman, O. (2007) The investigation of metal concentrations in street dust samples in Aqaba city, Jordan. Environ Geochem Health, 29: 197-207.

Al-Khashman, O.A. (2004) Heavy metal distribution in dust, street dust and soil from the work place in KarakIndustrial Estate, Jordan. Atmospheric Environment, 38: 6803-6812.

Al-Khashman, O. and Shawabkeh, R. (2006) Metal distribution in soils around the cement factory in southern Jordan. Environmental Pollution, 140: 387-394.

Alloway, B.J. (1990) Heavy metals in soils. London: Blackie. 
Al-Shayep, S.M. and Seaward, M.R.D. (2001) Heavy metal content of roadside soils along ring road in Riyadh (Saudi Arabia). Asian Journal of Chemistry, 13: 407-423.

Arslan, H. (2001). Heavy metals in street dust in Bursa, Turkey. Journal of Trace and Microprobe Techniques, 19: 439-445.

Bakirdere, S. and Yaman, M. (2008) Determination of lead, cadmium and copper in roadside soil and plants in Elazig, Turkey. Environ. Monit. Assess., 136: 401-410.

Banerjee, A.D.K. (2003) Heavy metal levels and solid phase speciation in street dusts of Delhi, India. Environmental Pollution, 123: 95-105.

Baptista, L.F. and De Miguel, E. (2005) Geochemistry and risk assessment of street dust in Luanda, Angola. A tropical urban environment. Atmospheric Environment, 39(25): 45014512 .

Birmili, W., Allen, A.G., Bary, F. and Harrison R.M. (2006) Trace Metal Concentrations and Water Solubility in Size-Fractionated Atmospheric Particles and Influence of Road Traffic. Environ. Sci. Technol., 40(4): 1144-1153.

Blok, J. (2005) Environmental exposure of road borders to zinc. The Science of the Total Environment, 348: 173-190.

Bocca, B., Alimonti A., Petrucci, F., Violante N., Sancesario G. and Forte G. (2004) Quantification of trace elements by sector field inductively coupled plasma spectrometry in urine, serum, blood and cerebrospinal fluid of patients with Parkinson's disease. Spectrochim Acta; B (59): 559-66.

Carreras, H.A. and Pignata, M.L. (2002) Biomonitoring of heavy metals and air quality in Cordoba city, Argentina, using transplanted lichens. Environmental Pollution, 17: 77-89.

Celik, A., Kartal, A., Akdogan, A. and Kaska, Y. (2005) Determination of heavy metal pollution in Denizli (Turkey) by using Robinio Pseudo-acacia L. Environmental International, 31: 105-112.

Charlesworth, S., Everett, M., McCarthy, R., Ordonez, A. and de Miguel, E. (2003) A comparative study of heavy metal concentration and distribution in deposited street dusts in a large and a small urban area: Birmingham and Coventry, West Midlands, UK. Environment International, 29: 563-573.

Chirenje, T., Ma, L.Q. and Lu, L. (2006) Retention of $\mathrm{Cd}, \mathrm{Cu}, \mathrm{Pb}$ and $\mathrm{Zn}$ by wood ash, lime, and fume dust. Water, Air and Soil Pollution, 171: 301-314.

Christoforidis, A. and Stamatis, N. (2009) Heavy metal contamination in street dust and roadside soil along the major national road in Kavala's region, Greece. Geoderma, 151: 257-263.

Divrikli, V., Soylak, M., Elic, L. and Dogan, M. (2005) Trace heavy metal levels in street dust samples from Yozgat City Center, Turkey. Journal of Trace and Microprobe Techniques 21(2): 351-361.

Doss, G.J., Elfving, D.C. and Lisk, D.J. (1995) Zinc in foliage downwind from a fire-burning plant. Chemosphere, 31(3): 2901- 2903.

Duggan, M.J. and Inskip, M.J. (1985) Childhood exposure to lead in surface dust and soil: a community health problem. Public Health Reviews, 13: 1-54.

Elik, A. (2003) Heavy metal accumulation in street dust samples in Sivas. Communications in Soil Science and Plant Analysis, 34(182): 145-156.

Fabis, W. (1987) Schadstoftbelastung von Bö den-Auswirkurgen auf Bö den-und wasserqalitat AllgFarstzeitsehr. BLV Verlaggesellshaft, Munich. pp. 128-131.

Fergusson, J.E. and Kim, N. (1991) Trace elements in street and house dusts: source and speciation. Sci. Total Environ., 100: 125-150.

Ferreira-Baptista, L. and De Miguel E. (2005) Geochemistry and risk assessment of street dust in Luanda, Angola: a tropical urban environment. Atmos. Environ.; 38: 4501-12.

Garg, B.D., Cadle, S.H., Mulaua, P.A., Groblicki, P.J. Laroo, C. and Parr, G.A. (2000) Brake wear particulate matter emissions. Environmental Science \& Technology, 34: 4463-4469. 
Golub, M.S., Han, B., Keen, C.L. and Gershwin, M.E. (1992) Effects of dietary aluminum excess and manganese deficiency on neurobehavioral endpoints in adult mice. Toxicol. Appl. Pharmacol., 112: 154-160.

Gregory, S. (1963) Statistical Methods and the Geographer, Longmans, London, $1^{\text {st }}$ edn.

Grigalaviciene, I., Rutkoviene, V. and Marozas, V. (2005) The accumulation of heavy metals $\mathrm{Pb}, \mathrm{Cu}$ and $\mathrm{Cd}$ at roadside forest soil. Polish Journal of Environmental Studies, 14: 109115.

Han, L., Zhuang, G., Cheng, S., Wang, Y. and Li, J. (2007) Characteristics of re-suspended road dust and its impact on the atmospheric environment in Beijing. Atmospheric Environment, 41(35): 7485-7499.

Harrison, R.M., and Perry, R.H. (1986) Hand Book of Air Pollution Analysis, 2nd edn. London, New York, Chapman and Hall.

Harrison, R.M. (1979) Toxic metals in street and household dusts. The Science of the Total Environment, 11: 89-97.

Harrison, R.M., Tilling, R., Romero, M.S.C., Harrad, S. and Jarvis, K. (2003) A study of trace metals and polycyclic aromatic hydrocarbons in the roadside environment. Atmospheric Environment, 37: 2391-2402.

Hewitt, C.N. and Candy, G.B.B. (1990) Soil and street dust heavy metal concentrations in and around Cuenca, Ecuador. Environmental Pollution, 63: 129-136.

Hildemann, L.M., Markowski, G.R. and Cass, G.R. (1991) Chemical composition of emissions from urban sources of fine organic aerosol. Environmental Science \& Technology, 25: 744759 .

Hjortenkrans, D., Bergback, B. and Haggerud, A. (2006) Newmetal emission patterns in road traffic environments. Environmental Monitoring and Assessment, 117: 85-98.

Joshi, U.M., Vijayaraghavan, K. and Balasubramanian, R. (2009) Elemental composition of urban street dusts and their dissolution characteristics in various aqueous media. Chemosphere 77(4): 526-533.

Kabata-Pendias, A. and Pendias, H. (1992) Trace elements in soils and plants $2^{\text {nd }}$ edition. Boca Raton, Florida7 CRC Press.

Karlsson K. and Viklander, M. (2008) Trace metal composition in water and sediment from catch basins, J. Environ. Eng., ASCE 134: 870-878.

Khoder, M.I., Hassan, S.K. and. El-Abssawy, A.A. (2010) An Evaluation of Loading Rate of Dust, $\mathrm{Pb}, \mathrm{Cd}$, and $\mathrm{Ni}$ and Metals Mass Concentration in the Settled Surface Dust in Domestic Houses and Factors Affecting Them. Indoor Built Environ. 19: 391-399.

Kim, K.W., Myung, J.H., Ahn, J.S. and Chon, H.T. (1998) Heavy metal contamination in dusts and stream sediments in the Taejon Area, Korea. Journal of Geochemical Exploration, 64: 409-419.

Koeppe, D.E. (1981) Lead: understanding the minimal toxicity of lead in plants. In: Leep, N.W. (Ed.), Effects of Trace Metals on Plant Function. Effects of Trace Metals on Plants, vol. 1. Applied Science Publishers, London, pp. 55-76 (Chapter 2).

Laidlaw, M.A.S., Mielke, H.W., Filippelli, G.M., Johnson, D.L. and Gonzales, C.R. (2005) Seasonality and children's blood lead levels: developing a predictive model using climatic variables and blood lead data from Indianapolis, Indiana, Syracuse, New York, and New Orleans, Louisiana (USA). Environ. Health Perspect. 113(6): 793-800.

Lau,W.M. and Wong, H.M. (1982) An ecological survey of lead contents in roadside dusts and soils in Hong Kong. Environmental Research 28: 39-54.

Leung, A.O.W., Duzgoren-Aydin, N.S., Cheung, K.C. and Wong, M.H. (2008) Heavy metals concentrations of surface dust from e-waste recycling and its human health implications in southeast China. Environ. Sci. Technol.,42: 2674-2680.

Li, X.D., Lee, S.L., Wong, S.C., Shi, W.Z. and Thornton, I. (2004) The study of metal contamination in urban soils of Hong Kong using a GIS-based approach. Environ. Pollut.; 129: 113- 24. 
Li, X.D., Poon, C.S. and Pui, S.L. (2001) Heavy metal contamination of urban soils and street dusts in Hong Kong. Applied Geochemistry, 1: 1361-1368.

Ljung, K., Selinus, O. and Otabbong, E. (2005) Metals in soils of children's urban environments in the small northern European city of Uppsala. Sci Total Environ; 366: 749-59.

López, J.M., Callén, M.S., Murillo, Garc'Ia, R.T., Navarro, M.V., de la Cruz, M.T. and Mastral, A.M. (2005) Levels of selected metals in ambient air PM10 in an urban site of Zaragoza (Spain). Environmental Research, 99: 58-67.

Lu, S.G. and Bai, S.Q. (2010) Contamination and potential mobility assessment of heavy metals in urban soils of Hangzhou, China: relationship with different land uses. Environ. Earth Sci., 60: 1481-1490.

Lu, X., Wang, L., Lei, K., Huang, J. and Zhai, Y. (2009) Contamination assessment of copper, lead, zinc, manganese and nickel in street dust of Baoji, NW China. Journal of Hazardous Materials, 161: 1058-1062.

Madany I.M., Akhter, M.S. and Al Jowder, O.A. (1994) The correlations between heavy metals in residential indoor dust and outdoor street dust in Bahrain. Environ Int., 20: 483-92.

Manta, D.S., Angelone, M., Bellanca, A., Neri, R. and Sprovieri, M. (2002) Heavy metals in urban soils: a case study from the city of Palerma (Sicily), Italy. Sci Total Environ., 300: $229-243$.

Markus, J.A. and McBratney, A.B. (1996) An urban soil study: heavy metals in Glebe, Australia. Australian Journal of Soil Research, 34: 453-465.

Massadeh, A., Al-Sharif, L., Dalale'h, R. and Hassanet, M. (2006) Analysis of lead levels in local Jordanian and imported sheep meat and organs using atomic absorption spectrometry. Environmental Monitoring and Assessment, 115: 87-93.

Monaca, F., Moni, F., Lanciotti, E., Grechi, D. and Bargagli, R. (2000) Biomonitoring of airborne metals in urban environments: new tracers of vehicle emission, in place of lead. Environ. Pollut., 107: 321-327.

Nabuloa, G., Oryem-Origab, H. and Diamond, M. (2006) Assessment of lead, cadmium, and zinc contamination of roadside soils, surface films, and vegetables in Kampala City, Uganda. Environmental Research, 101: 42-52.

Ndiokwere, C.L. (1984) A study of heavy metal pollution from motor vehicle emissions and its effect on roadside soil, vegetation and crops in Nigeria. Environmental Pollution (Series B) 7: $35-42$.

Olajire, A. and Ayodele, E.T. (1997) Contamination of roadside soil and grass with heavy metals. Environment International, 23(1): 91-101.

Ordonez, A., Loredo, J., de Miguel, E. and Charlesworth, S. (2003) Distribution of heavy metals in street dust and soils of an industrial city in northern Spain. Archives of Environmental Contamination and Toxicology 44: 160-170.

Ozkan, M.H., Gurkan, R., Ozkan, A. and Akcay, M. (2005) Determination of manganese and lead in roadside soil samples by FAAS with ultrasound assisted leaching. Journal of Analytical Chemistry, 60: 469-474.

Piron-Frenet, M., Bureau, F. and Pineau, A. (1994) Lead accumulation in surface roadside soil: its relationship to traffic density and meteorological parameters. Sci Total Environ., 144: 297-304.

Ramlan, M.N. and Badri, M.A. (1989) Heavy metals in tropical city street dust and roadside soils: a case of Kuala Lumpur, Malaysia. Environmental Technology Letters, 10: 435-444.

Robertson, D.J., Taylor, K.G. and Hoon, S.R. (2003) Geochemical and mineral magnetic characterization of urban sediment particulates, Manchester, UK. Applied Geochemistry, 18: $269-282$.

Schwar, M.J.R., Moorcroft, J.S., Laxen, D.P.H., Thomson, M. and Armorgie, C. (1988) Baseline metal-in-dust concentrations in Greater London. The Science of the Total Environment, 68: 25-43. 
Sezgin, N., Ozcan, H.C., Demir, G., Nemlioglu, S. and Bayat, C. (2003) Determination of heavy metal concentrations in street dusts in Istanbul E-5 highway. Environment International, 29: 979-985.

Sternbeck, J., Sjodin, A. and Andreasson, K. (2002) Metal emissions from road traffic and the influence of resuspension-results from two tunnel studies. Atmospheric Environment, 36: 4735-4744.

Sutherland, R.A. and Tolosa, C.A. (2000) Multi-element analysis of road deposited sediment in an urban drainage basin, Honolulu, Hawaii. Environmental Pollution, 110: 483-495.

Tokalioglu, S. and Kartal, S. (2006).Multivariate analysis of the data and speciation of heavy metals in street dust samples from the Organized Industrial District in Kayseri (Turkey). Atmospheric Environment 40: 2797-2805.

Tume, P., Bech, J., Sepulveda, B., Tume, L. and Bech, J. (2008) Concentrations of heavy metals in urban soils of Talcahuano (Chile): a preliminary study. Environ. Monit. Assess, 140: 91-98.

Tüzen, M. (2003) Determination of heavy metals in soil, mushroom and plant samples by atomic absorption spectrometry. Micro chemical Journal, 74: 289-297.

Viard, W., Pihan, F., Promeyrat, S. and Pihan, J.C. (2004) Integrated assessment of heavy metal $(\mathrm{Pb}, \mathrm{Zn}, \mathrm{Cd})$ highway pollution: Bioaccumulation in soil, Graminaceae and land snails. Chemosphere, 55: 1349-1359.

Waisberg, M., Joseph, P., Hale, B. and Beyersmann, D. (2003) Molecular and cellular mechanisms of cadmium carcinogenesis. Toxicology; 192: 95-117.

Whicker, C.L., Hayes, W.J., Khoo, C.S. and Athol, B.H. (1997) Heavy metals in ceiling dust of some Sydney houses, New South Wales, Australia. Journal of Proceedings of the Royal Society NSW 130: 65-78.

Wilcke, W., Muller, S., Kanchanakool, N. and Zech, W. (1998) Urban soil contamination in Bangkok: heavy metal and aluminum portioning in top soils. Geoderma, 86: 211-228.

Willers, S., Gerhardsson, L. and Lundh, T. (2005) Environmental tobacco smoke (ETS) exposure in children with asthma-relation between lead and cadmium, and nicotine concentrations in urine. Respiratory Medicine 99: 1521-1527.

Yassoglou, N., Kosmas, C., Asimacopoulos, J. and Kallianou, C. (1987) Heavy metal contamination of roadside soils in the Greater Athens Area. Environmental Pollution 47: 293-304.

Yongming, H., Peixuan, D., Junji, C. and Posmentier, E. (2006) Multivariate analysis of heavy metal contamination in urban dusts in Xian, central China. The Science of the Total Environment, 355: 176-186.

Yunker, M.B., Macdonald, R.W., Vingarzan, R., Mitchell, R.H., Goyette, D. and Sylvestre, S. (2002) PAHs in the Fraser River basin: a critical appraisal of PAH ratios as indicators of PAH source and composition. Organic Geochemistry 33: 489-515.

Zhang, M.K. and Wang, H. (2009) Concentrations and chemical forms of potentially toxic metals in road-deposited sediments from different zones of Hangzhou, China, J. Environ. Sci. - China 21: 625 -631.

Zheng, N., Liu, J., Wang, Q. and Liang, Z. (2010) Health risk assessment of heavy metal exposure to street dust in the zinc smelting district, Northeast of China. Science of the Total Environment 408: 726-733. 
توزيع العناصر الثقيلة في أتربة الثوارع بالمناطق الحضرية والصناعية بمدينة جدة - المملكة العربية السعودية

ممدوح إبراهيم خضير، و منصور أحمد الغامدى، و محمد حمد شيبوب قسم العلوم البيئية، كلية الأرصاد والبيئة وزراعة الدناطق الجافة، جامعة الملك عبدالعزيز، جدة - المدلكة العربية السعودية

المستخلص. نم تقدير نركيز العناصر النقبلة (الرصاص - النيكل الكادميوم - الكروم - النحاس - الزنلك - الحديد - المنجنيز ) في لردي الني

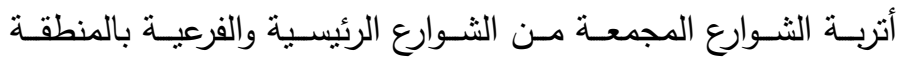
الحضرية (حي الجامعـة) وكذلك من المنطقة الصناعية في مدينـة جدة - المملكة العربية السعودية. أوضحت الدراسـة أن أعلى تركيز

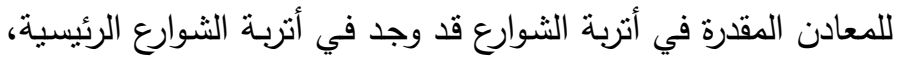

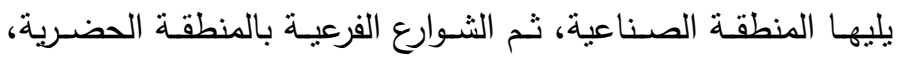

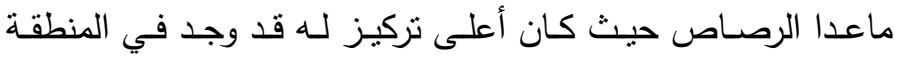
الصناعية. وقد وجد أن متوسط تركيزات المعادن منفردة في أتربـة

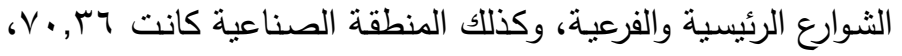

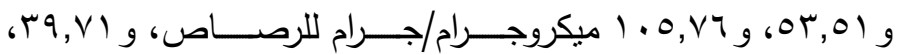
و • •

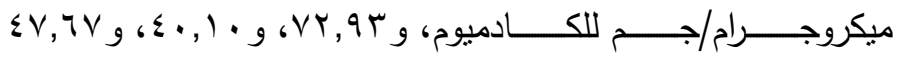

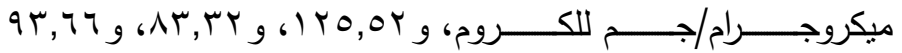

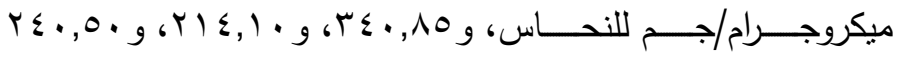

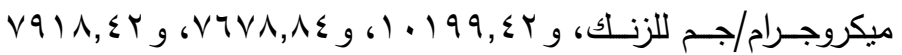

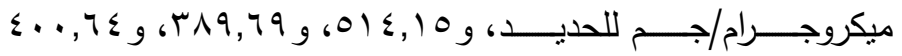
ميكروجرام/جم للمنجنيز ، على التوالي. كان منوسط نسب نركيز 
المعـادن في أتربـة الثـوارع الرئيسية إلى نركيزاتها في أتربـة الثـوارع

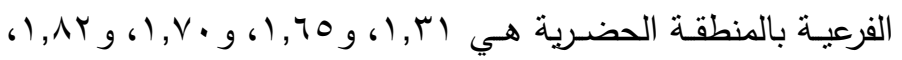

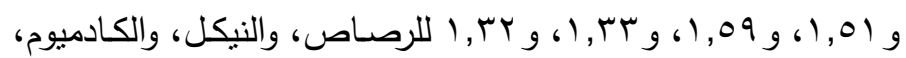

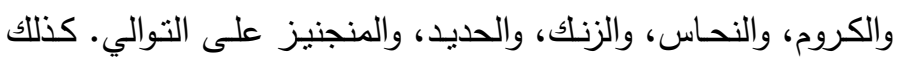

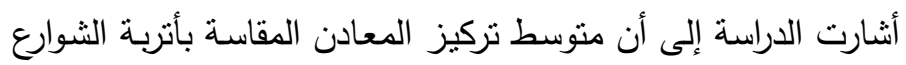

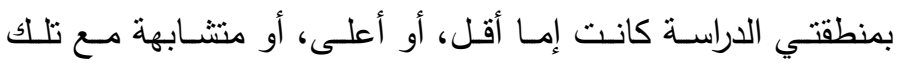

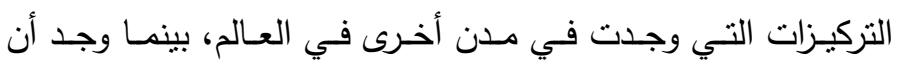

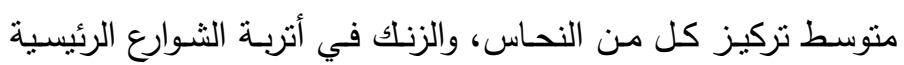

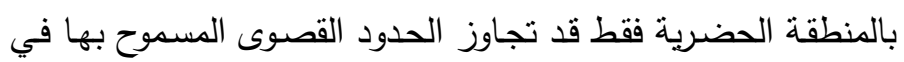

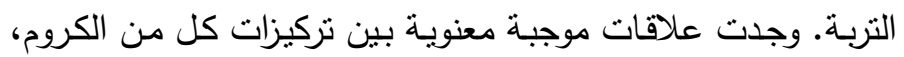
والكادميوم، والنحاس، والزنك، وكذللك بين تركيزات كل من الحديد، والمنجنيز ، وتركيزات كل من النيكل، والكروم، والنحاس، والزنلك في ولني

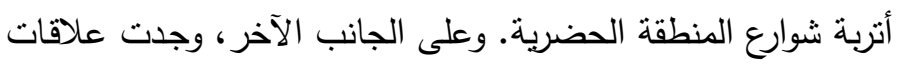

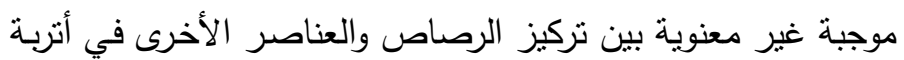

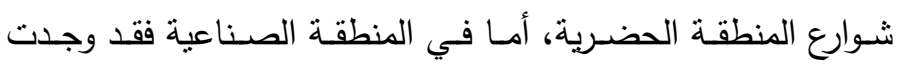

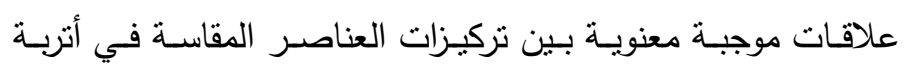
الثوارع.

الكلمات الدالة: المعادن الثقبلة، اتربة الثوارع، منطقة حضرية، منطقة صناعية، شوارع رئيسية وفرعية، جدة 